\title{
Incidence of HIV-infected infants born to HIV. infected mothers with prophylactic therapy: Preliminary report of hospital birth cohort study
}

\author{
Nia Kurniati, T Nilamsari, Arwin AP Akib
}

\begin{abstract}
Background Human immunodeficiency virus (HIV) is expanding rapidly and was reported double in several places in Indonesia To our knowledge, reports regarding HIV-infected infants are still scarce.

Objectives To investigate the incidence of HIV-infected infants born to HIV- mothers who had received prophylaxis therapy at birth. Methods A prospective hospital-based cohort study was held from January 2003 until December 2004 in Cipto Mangunkusumo Hospital, Jakarta. The inclusion criteria were mothers with positive HIV and their infants had been given anti retroviral (ARV) therapy. The babies were followed up monthly and the status of infection was determined by PCR at the age of 4 weeks and 6 months. Outcome was measured based on PCR assays or clinical signs of HIV infection.

Results The mothers' age ranged from 19 to 27 years. All of them were carrying their first child and only $41 \%$ mothers took ARV prophylaxis. Almost all mothers underwent caesarean section and the infants had formula feeding. HIV infection was diagnosed in 7 infants and 2 of them had RNA assays more than 5,000 copies $/ \mathrm{ml}$. Six infants were negatives whereas 3 infants were diagnosed as indeterminate HIV infection and needed further examination. One needed no further investigation as the mother was seronegative.

Conclusions Preventing HIV transmission from mother to infant can be done by giving ARV during prenatal, intrapartum, and postnatal period to the newborn. In our hospital, transmission was confirmed in 6 of 17 infants. Unison protocol must be used and population of HIV-pregnant mother must be registered in order to know how high the transmission rate among Indonesian HIV people [Paediatr Indones 2006;46:209-213].
\end{abstract}

Keywords: HIV, HIV-pediatric, mother-to-child transmission
I ndonesia is now experiencing rapid expansion of human immunodeficiency virus (HIV) epidemics. Several places reported double increase of incidence in the last 5 years. In cities where injecting drug users were a problem, HIV infections also accounted for a rise of mortality. ${ }^{1}$ Adolescents and early adults were mostly drug-abusers, and they were at the age of sexually active life. The risk to transmit HIV to a spouse leads also to the transmission of HIV risk pregnancy, and ultimately to HIV exposed infant.

Developed countries reported that by conducting prevention program of mother to child transmission, the rate of transmission is currently below $2 \% .2,3$ Efforts consist of recommendation for universal prenatal HIV counseling and testing, widespread use of highly active antiretroviral (ARV) therapy and elective cesarean delivery on HIV-infected pregnant women.

Department of Health of Indonesia assumes that there are 2,000-3,000 pregnant women with HIV in Indonesia in 2004. ${ }^{4}$ Those HIV-mothers

From the Department of Child Health, Medical School, University of Indonesia, Jakarta, Indonesia.

Reprint request to: Arwin AP Akib, MD, Division of Pediatric Allergy and Immunology, Department of Child Health, Medical School, University of Indonesia, Jl. Salemba No.6, Jakarta, Indonesia. Tel. 021-3161144. 
given ARV therapy later during delivery were not yet reported. National prevention program of mother to child transmission is intended to be implemented in the recent year.

Our immunology clinic treats infants born to mothers with HIV since $1996 .{ }^{5}$ The rate of HIV-transmitted infants prone to ARV prophylaxis at birth have not been evaluated. The objective of this study was to investigate the incidence of HIV-infected infants born to mother with HIV who had received prophylaxis therapy at birth. This was only a preliminary report of a much longer hospital birth cohort project.

\section{Methods}

This was a prospective hospital-based cohort study with short-term follow-up. The study participants were HIV-1 exposed infants who attended our HIV clinic, Department of Child Health, Cipto Mangunkusumo Hospital, Jakarta, from January 2003 to December 2004. They were born in our maternity department or other hospitals and aged less than 2 weeks. The inclusion criteria were mother with positive HIV whether they had or had no ARV before pregnancy, delivery, during delivery, or post-delivery periods. The study infants had to have zidovudine with or without nevirapine since the age of 12 hours.

Data of parents and infants were recorded. Maternal data included maternal age, risk factors, $\mathrm{CD}^{+}{ }^{+}$count, viral RNA levels before delivery, mode of delivery and information whether she nursed her baby or not. Paternal risk factors were also recorded. Data of infants included viral RNA detection, $\mathrm{CD}^{+}{ }^{+}$count, and clinical condition. The exclusion criteria were no ARV given to HIVexposed infants for prophylaxis or unknown HIV status of the mothers.

Every baby was then followed-up monthly as it was done to healthy infants and was given immunization according to protocol set up for exposed infants. After the age of 6 months, infection status was determined based on polymerase chain reaction (PCR) on ribonucleic acid (RNA), serology after 12 months or any sign of HIV infection. Diagnosis of HIV infection was established using viral diagnostic assays at the age of 4 weeks and older than 6 months. Clinical diagnosis of HIV was established according to 1994
Center of Disease Control criteria. Immuno-suppression status was also examined if there were clinical or laboratory signs of infection.

The end point of the study was confirmation of HIV-infection status in infants with positive PCR assays on separate blood specimen. Infection could also be established if there were clinical signs of HIV infection. Uninfected infants could be determined with 2-negative virology assay on separate blood samples. If the parents could not afford PCR test, HIV immunoglobulin $G$ ( $(g G)$ antibody test performed at the age of more than 6 months with an interval of at least 1 month between the tests could also be used to exclude HIV infection. If there was only 1 sample tested, both in virology assay and in serologic test, clinical sign of HIV would confirm HIV infection; otherwise infection status would be indeterminate until the end of study.

\section{Results}

From January 2003 until December 2004, 17 neonates born to HIV-infected mothers attended our HIV clinic. Their mothers' age ranged from 19 to 27 years. Almost all mothers were carrying their first child. During pregnancy only 7 mothers took ARV prophylaxis, ranged from 1 week before delivery to the entire pregnancy period. HIV status of the mother was confirmed by serology antibody test using enzymelinked immunosorbent assay (ELISA). Immunosuppression status was determined only in 9 mothers, with all $\mathrm{CD}^{+}>200$ cells/ml. Only 2 mothers had virology assay data, one was 234 copies $\mathrm{RNA} / \mathrm{ml}$ and the other one was 26,551 copies $\mathrm{RNA} / \mathrm{ml}$.

The risk factors of HIV infections were not all described in their medical records since there was great possibility that these mothers got the infection from their husbands as it is shown in Table 1. Paternal risks recorded were mostly intravenous (IV) drug users. Only 2 parents probably had infection through multiple sex partners.

Almost all mothers (16/17) underwent cesarean section, and all infants were given formula feeding to avoid transmission via breast feeding. All but 1 infants were born full-term and their birth weight ranged from 2370-3900 grams. All of these infants were still on our monitoring to be followed later. 
Table 1. Characteristics of parents

\begin{tabular}{lc}
\hline Risk factors & \\
Paternal IVDU-maternal IVDU & 2 \\
Paternal IVDU only & 9 \\
Paternal MPS-maternal MPS & 2 \\
Maternal MPS only & 0 \\
$\quad$ No data & 4 \\
Maternal viral level & 2 \\
$\quad$ Determined & 15 \\
$\quad$ Not determined & \\
Maternal CD4+ count & 9 \\
$\quad$ Determined & 8 \\
Not determined & \\
ARV during pregnancy & 1 \\
$\quad$ 1 month & 1 \\
1 month & 5 \\
$\quad$ N month & 10 \\
Not received & \\
Mode of delivery & 16 \\
Elective sectio caesarian & 1 \\
\hline Spontaneous labor &
\end{tabular}

Abbreviation: IVDU=intravenous drug user; MPS=multiple partner sex; $\mathrm{ARV}=$ anti-retroviral

HIV infection was diagnosed in 7 patients, 2 of them were categorized as confirmatory infection because viral RNA level reached $>5,000$ copies $/ \mathrm{ml}$. Both received ARV therapy. Three patients had RNA assays $<400$ copies $/ \mathrm{ml}$ and no clinical sign of HIV infection was noted nevertheless 2 of these 3 were given ARV therapy. The reason why 1 out of these 3 patients was not given ARV was adherence consideration. One patient did not have virology assay result because of financial reason, he developed clinical sign that fulfilled CDC criteria 1987; and we entered him into ARV therapy. One last case had 1 negative virology assay, but he developed BCG-itis so that we gave him ARV therapy (Table 2).

The descriptions of the rest of 10 infants are as follow. Two-negative PCR RNA examined on 4 weeks and $>6$ months of age were revealed in 6 infants. Those infants were considered as HIV uninfected. One negative assay was found among 3 infants, 2 of them were reported to be unable to undergo second PCR assay due to financial problem. The others were not reaching 6 months of age at the end of the study. In these 4 infants, HIV-infections were still indeterminate, although 1 infant developed BCG-itis that we suspected immunocompromised condition. Further data will be needed to confirm their status.

One infant was considered as uninfected even though she did not undergo virology examination. Her mother serology test showed negative result on postnatal repeated examination, although her husband was proven to be positive HIV.

\section{Discussion}

This study was intended to be a model for a longer cohort study. It was not an ideal model to describe HIV transmission rate among Jakarta's infants population born to HIV-infected mother since we were not exposed to all HIV mothers. In this short cohort, we were anxious to know the impact of giving ARV prophylaxis to these infants.

According to prevention program of mother to child transmission (PMTCT), perinatal HIV transmission was accounted for virtually all cases in our study. Transmissions in this vertical mode occurred before delivery (prepartum), during delivery (intrapartum), and after delivery through breastfeeding. Published transmission rate worldwide varied from $2 \%$ in developed countries to $40 \%$ in Africa. Populationbased cohort study showed that with implementation

Table 2. Description of positive cases

\begin{tabular}{cccccccc} 
Case & $\begin{array}{c}\text { Maternal } \\
\text { viral level } \\
\text { (copies/ml) }\end{array}$ & $\begin{array}{c}\text { CD4 } \\
\text { (cell/mI) }\end{array}$ & $\begin{array}{c}\text { Mode of } \\
\text { delivery }\end{array}$ & $\begin{array}{c}\text { Infant viral level } \\
\text { age } \mathbf{4} \text { weeks } \\
\text { (copies/ml) }\end{array}$ & $\begin{array}{c}\text { Clinical } \\
\text { condition }\end{array}$ & ARV therapy & Results \\
\hline 1 & NA & 925 & SC & $<400$ & Healthy & No & Indeterminate \\
2 & NA & $>200$ & SC & 8,839 & Healthy & ZDV 3Tc NVP & HIV-infected \\
3 & NA & 316 & SC & $<400$ & Healthy & ZDV 3Tc NVP & Indeterminate \\
4 & NA & NA & SC & 246,509 & Healthy & ZDV 3Tc & HIV-infected \\
5 & NA & NA & SC & 372 & Healthy & ZDV 3Tc & Indeterminate \\
6 & NA & NA & SC & NA & Impetigo FTT & ZDV 3Tc NVP & HIV-infected \\
7 & 26.551 & 324 & SC & Not detected & BCG-itis & ZDV 3Tc & Indeterminate \\
\hline
\end{tabular}

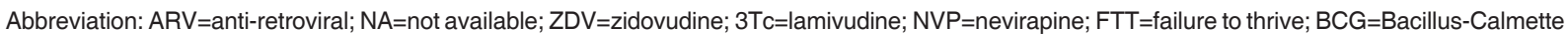
Guerein 
of PMTCT transmission rate can be suppressed to 4 $15 \%{ }^{6}$

Our patients were infants born to HIV-positive mothers who were managed to escape HIV infection by prevention at least with treatment for the baby. Unison protocol of the mother varied over time during the study, because the infant received only zidovudine in the year 2003 and received nevirapine as additional treatment in the year 2004. Zidovudine was given for 6 weeks, with doses of $2 \mathrm{mg} / \mathrm{kgBW}$ every 6 hours. This protocol proved to be effective in study of PACTG $76 .{ }^{7}$ Nevirapine $2 \mathrm{mg} / \mathrm{kgBW}$ as a single dose was added for infant born to ARV-naïve mother, according to study of CDC-Thailand. ${ }^{8}$

Retrieving paternal risk factors is usually difficult. They are usually reluctant to disclose their status. From all data that we could gather, recent or previous IV drug user was the important source of HIV infection in this family. Study from Jakarta revealed that as high as $75 \%$ of drug user infected with HIV. ${ }^{9}$

Maternal viral RNA levels, lower $\mathrm{CD}^{+}{ }^{+}$counts, advance maternal disease, prolonged duration of ruptured membranes, chorioamnionitis, and associated diseases were reported to increase risk of HIV transmission. ${ }^{10}$ Only 2 mothers had data of viral levels and only 8 mothers had data of $\mathrm{CD}^{+}$counts during pregnancy. One mother had viral RNA level $>10,000$ copies $/ \mathrm{ml}$ and $\mathrm{CD}^{+}{ }^{+}$count $>200 \mathrm{cell} / \mathrm{ml}$. It turned out that her infant was negative on first PCR determination. BCG-itis developed at the age of 4 months and persisted for 3 months in spite of well-baby condition. He was treated as HIV-infection even though infection status was indeterminate. He was given ARV therapy. When facing such situation, single negative viral test in symptomatic HIV-infected children should lead to suspicion of HIV infection. Although symptoms of HIV infection overlapped with those of other common childhood diseases, repeated virology test is recommended in this patient to confirm diagnosis. $2,3,5$

Study of pediatric AIDS clinical trials group (PACTG) protocol 076 showed that by giving zidovudine at prenatal and intrapartum period to the mother along with zidovudine 4 times a day for 6 weeks to the newborn, transmission rate can be suppressed to $7.6 \% .{ }^{7}$ Furthermore, collaborative study of $\mathrm{CDC}$ and Thailand using prenatal zidovudine, intrapartum zidovudine plus nevirapine, and zidovudine plus nevirapine for the newborn showed that transmission rate was as low as $4.6 \% .^{8}$ Both studies were done on population of HIV-infected mother. In this study we could not attribute to a certain PMTCT protocol. Difficulties in early detection of HIV-pregnant mothers led us to late confirmation of HIV infection in near-labor mother so that we had no chance to give ARV before delivery. The data showed that we had only 6 of 17 infants which later turned out to be HIV-positive infection and 1 case of indeterminate HIV infection by giving at least ARV to the newborn.

In 1 case whose mother was considered as negative, rechecking of data and laboratory reagent usage should be performed. In this state, retesting in separate times would alleviate window period or different sensitivity of different reagent tested.

In conclusion, preventing HIV transmission from mother to infant can be done by giving ARV during prenatal, intrapartum, and postnatal period to the newborn. In our hospital, transmission was confirmed in 6 of 17 infants. Unison protocol must be used and population of HIV-pregnant mother must be registered in order to know how high the transmission rate among Indonesian HIV people.

\section{References}

1. World Health Organization-regional office for SouthEast Asia. HIV/AIDS facts and figures. Cited 2004 September 9. Available from http: url: //www.who/ searo/HIV-AIDS/factsandfigure.htm.

2. The Working Group on Antiretroviral and Medical Management of HIV-Infected Children, The National Resources and Services Administration, and The National Institute of Health. Guidelines for the use of antiretroviral agents in pediatric HIV infection. Cited 2004 November 30. Available from: url: http:// www.aidsinfo.org.

3. Dorenbaum A, Cunningham CK, Gelber RD, Culnane M, Mofenson LM, Britto P, et al. Two-dose intrapartum/newborn nevirapine and standard antiretroviral therapy to reduce perinatal HIV transmission. JAMA 2002;288:189-98.

4. Ditjen PPM\&PL Departemen Kesehatan Republik Indonesia. Laporan triwulan pengidap infeksi HIV dan kasus AIDS sampai dengan Desember 2004.

5. Akib AAP. Infeksi HIV pada bayi dan anak. Pertemuan Ilmiah Tahunan Ikatan Dokter Anak Indonesia. Batam. June 2004. 
6. Mofenson LM. Overview of perinatal intervention trials. Cited 2005 March. Available from: url: http:// www.womenchildrenhiv.org/

7. McSherry GD, Shapiro DE, Coombs RW. The effect of zidovudine in the subset of infants infacted with human immunodeficiendy virus type-1 (Pediatric AIDS clinical trials group protocol 076). J Pediatr 1999;134: $717-24$.

8. Chalermchokcharoenkit A, Asavapiriyanont S, Teeraratkul A, Vanprapa N, Chotpitayasunondh T, Chaowanachan $\mathrm{T}$, et al. Combination short-course zidovudine plus 2-dose nevirapine for prevention of mother-to-child transmission: Safety, tolerance, transmission, and resistance results. 11th Retrovirus and Opportunistic Infection Conference. San Fransisco, February 2004.

9. Djauzi S, Djoerban Z. Penatalaksanaan infeksi HIV di pelayanan kesehatan dasar. Edisi ke-2. Jakarta: Balai Penerbit FKUI; 2003. p. 67.

10. Ammann AJ. Pediatric human immunodeficiency virus infection. In: Stiehm ER, Ochs HD, Winkelstein JA, editors. Immunologic disorders in infants and children. 5th edition. Philadelphia: Elsevier Saunders; 2004. p. 878-951. 